\title{
Infection dynamics of Amoebophryidae parasitoids on harmful dinoflagellates in a southern Chilean fjord dominated by diatoms
}

\author{
Catharina Alves-de-Souza ${ }^{1,2,3,8, *}$, Daniel Varela ${ }^{4}$, José Luis Iriarte ${ }^{5,6,7}$, \\ Humberto E. González ${ }^{1,6,7}$, Laure Guillou ${ }^{2,3}$

\footnotetext{
${ }^{1}$ Instituto de Ciencias Marinas y Limnológicas, Universidad Austral de Chile, PO Box 567, Valdivia 5090000, Chile ${ }^{2}$ Université Pierre et Marie Curie, Paris 6, Station Biologique de Roscoff, Place Georges Teissier, Roscoff 29680, France ${ }^{3}$ Centre National de la Recherche Scientifique (CNRS), UMR 7144, Laboratoire Adaptation et Diversité en Milieu Marin, Place Georges Teissier, Roscoff 29680, France

${ }^{4}$ Centro de Investigación I-mar, Universidad de los Lagos, Casilla 557, Puerto Montt 5480000, Chile

${ }^{5}$ Instituto de Acuicultura, Universidad Austral de Chile, Los Pinos s/n, Puerto Montt 5480000, Chile

${ }^{6}$ Centro COPAS y COPAS Sur Austral, Universidad de Concepción, PO Box 160-C, Concepción 4030000, Chile

${ }^{7}$ Centro de Investigación de Ecosistemas de la Patagonia (CIEP), Coyhaique 5950000, Chile
}

${ }^{8}$ Present address: Laboratório de Ficologia, Departamento de Botânica, Museu Nacional/Universidade Federal do Rio de Janeiro, Quinta da Boa Vista S/N, São Cristóvão, Rio de Janeiro, RJ 20940-040, Brasil

\begin{abstract}
Parasitoids belonging to Amoebophryidae (Marine ALVeolate Group II or MALV II) infecting dinoflagellates were investigated in Reloncaví Fjord (southern Chile) in the austral summer 2009. Of the 12 dinoflagellate species recorded during monthly sampling, Prorocentrum micans, Dinophysis acuminata, and Phalacroma rotundata were infected by Amoebophrya spp. To assess parasitoid control of host populations, the short-term dynamics of Amoebophrya spp. were followed for $21 \mathrm{~d}$ during a bloom of $P$. micans. Host mortality induced by Amoebophrya spp. (\% hosts killed per day) was estimated by dividing prevalence by the generation time of these parasitoids. Parasitism by Amoebophrya spp. was responsible for $\sim 10 \%$ of $P$. micans mortality between 8 and 17 March. The small subunit rDNA genes of individual parasitoids infecting different host cells were sequenced, and like most environmental sequences retrieved from this ecosystem in January and February, all belonged to the MALV II Clade 4. However, as soon as the P. micans bloom was detected, the MALV II genetic composition changed drastically, with the detection of Clades 1 , 4 (a different sub-cluster than before), 5, 6, and 12. Our results suggest that different types of parasitoids belonging to Amoebophryidae likely infect dinoflagellates in Reloncaví Fjord, offering the first demonstration of the presence of important genetic diversity in MALV II inhabiting an ecosystem where dinoflagellate hosts are not the usual dominant phytoplanktonic organisms.
\end{abstract}

KEY WORDS: Amoebophrya $\cdot$ MALV II · Parasitism · Harmful algal blooms

\section{INTRODUCTION}

The southern region of Chile $\left(41-56^{\circ} \mathrm{S}\right)$ includes a variety of embayments, fjords, and channels characterized by high productivity. Phytoplankton abundance in this area is strongly influenced by the inter- action between silicic acid $\left(\mathrm{Si}(\mathrm{OH})_{4}\right)$ input from freshwater discharge and the vertical entrainment of nitrate $\left(\mathrm{NO}_{3}\right)$ and orthophosphate $\left(\mathrm{PO}_{4}\right)$ from subantarctic waters (Iriarte et al. 2007, Torres et al. 2011). The constant supply of $\mathrm{Si}(\mathrm{OH})_{4}$ from river discharge drives the high $\mathrm{Si}(\mathrm{OH})_{4}: \mathrm{NO}_{3}$ and $\mathrm{Si}(\mathrm{OH})_{4}: \mathrm{PO}_{4}$ 
ratios typically observed in these systems, which probably explains why diatoms are usually the predominant phytoplankton group throughout the year (Alves-de-Souza et al. 2008). It was recently suggested that drastic reductions of precipitation in southern Chile might result in lower flows from rivers and glaciers (Lara et al. 2005). This could, in turn, reduce the silicate load and cause a decline of overall fjord productivity (e.g. Rebolledo et al. 2005, Sepulveda et al. 2005). The lower ratios of $\mathrm{Si}(\mathrm{OH})_{4}: \mathrm{NO}_{3}$ and $\mathrm{Si}(\mathrm{OH})_{4}: \mathrm{PO}_{4}$ might favor species that do not require silicates, such as dinoflagellates, at the expense of diatoms (Iriarte et al. 2010). Many dinoflagellate species produce harmful algal blooms (HABs) that might be noxious to both humans and aquatic ecosystems (Smayda 1997). Thus, the frequency of HABs caused by dinoflagellates within Chilean fjords might be expected to increase. The main dinoflagellate species related to HABs in southern Chile are Alexandrium catenella and Dinophysis spp., recurrently associated with outbreaks of paralytic and diarrheic toxins, respectively (Lembeye et al. 1993, Guzmán et al. 2002, Molinet et al. 2003). Although less frequent, other dinoflagellate species, such as Prorocentrum micans, Gymnodinium cf. chlorophorum, and Gymnodinium sp., have also been recorded to form $\mathrm{HABs}$, causing behavioral changes and mortality in wild and farmed aquatic resources (Lembeye \& Campodónico 1984, Uribe \& Ruiz 2001, Iriarte et al. 2005).

Although studies of HAB dynamics usually focus on the role of bottom-up factors, growing evidence shows the importance of biotic factors, mainly grazing and parasitism, in the demise of blooms (e.g. Calbet et al. 2003, Montagnes et al. 2008). It has recently been postulated that dinoflagellate blooms may also result from the absence of efficient pathogens in newly invaded areas (Salomon et al. 2003, Chambouvet et al. 2008), a theory known as the 'enemy release hypothesis' in terrestrial ecology (Keane \& Crawley 2002). The major eukaryotic pathogens described for dinoflagellates are unicellular parasitoids belonging to the Phylum Alveolata (perkinsoids and Amoebophryidae; Park et al. 2004). Both lineages ultimately kill their hosts to accomplish their life cycles (Park et al. 2004), endowing these organisms with a typical parasitoid feature (i.e. parasitism is similar to predation by grazers in that a part of the host population will be killed). Although perkinsoids are rarely reported in environmental genetic surveys, Amoebophryidae (synonymous to Marine ALVeolate Group II or MALV II) is one of the most important eukaryotic genetic lineages retrieved from marine ecosystems
(Guillou et al. 2008). To date, Amoebophryidae is only composed of one genus, Amoebophrya, but this group is likely much more complex in terms of genetic diversity. Within the genus Amoebophrya, several species have been described as infecting a large number of dinoflagellate species (Park et al. 2004). The life cycle of these parasitoids begins with a small infective biflagellate cell (the dinospore) entering the host cell (Cachon 1964). Maturation takes 2 to $3 \mathrm{~d}$ and eventually leads to the death of the host and liberation of a long, worm-shaped, motile filament of biflagellate cells (the vermiform stage). Within a few hours, the vermiform stage fragments and releases hundreds of new infective dinospores (Coats \& Bockstahler 1994, Coats \& Park 2002), each potentially capable of infecting a novel host. Both field observations and model predictions indicate that these parasitoids have the capacity to efficiently control their dinoflagellate host populations (Cachon 1964, Coats et al. 1996, Chambouvet et al. 2008, Montagnes et al. 2008, Salomon \& Stolte 2010).

Interactions between Amoebophrya spp. and their hosts have been assessed mainly in coastal areas of the northern hemisphere (Cachon 1964, Taylor 1968, Fritz \& Nass 1992, Coats \& Bockstahler 1994, Coats et al. 1996, Maranda 2001, Chambouvet et al. 2008). These studies have indicated that a moderate to high prevalence of Amoebophrya spp. (20 to $80 \%$ ) is usually observed during annual dinoflagellate blooms in estuarine systems, where high nutrient concentrations and water mass stability favor the growth of dinoflagellates. However, recent studies in oligotrophic coastal waters of Brazil (Salomon et al. 2009) and ultra-oligotrophic waters of the Mediterranean Sea (Siano et al. 2011) have reported Amoebophrya spp. infections of dinoflagellates with prevalences up to 7 and $25 \%$, respectively, suggesting that these parasitoids could also be relevant at low host concentrations.

Considering the growing occurrence of HABs caused by dinoflagellates in Chile, it is important to explore the capacity of Amoebophryidae parasitoids to successfully infect dinoflagellates in the coastal waters of this country. The main objectives of this study were (1) to evaluate the presence of these parasitoids in an ecosystem usually dominated by diatoms throughout the year and (2) to assess the capacity of Amoebophryidae to infect and control bloom-forming dinoflagellate species. The sampling strategy consisted of monthly monitoring at a fixed station in Reloncaví Fjord, an ecosystem supporting a high salmon farming activity in southern Chile, and exploring the small subunit (SSU) rDNA genetic diversity of Amoebophryidae using culture-indepen- 
dent methods and the direct sequencing of infected host cells. As soon as a dinoflagellate bloom was detected, a higher frequency sampling strategy was employed to evaluate the capacity of these parasitoids to efficiently propagate infections and control their hosts. The present work constitutes the first record of Amoebophryidae infection dynamics in southern Pacific waters.

\section{MATERIALS AND METHODS}

\section{Study area and sample collection}

Situated as the closest fjord to the equator in the world, Reloncaví Fjord $\left(\sim 41.6^{\circ} \mathrm{S}\right)$ is one of the most representative estuarine systems in southern Chile (Fig. 1). It is $\sim 60 \mathrm{~km}$ long, covers $170 \mathrm{~km}^{2}$, and has a maximum depth of $460 \mathrm{~m}$. The present study was performed in austral summer 2009 at a sampling station $\sim 20 \mathrm{~m}$ deep located at the head of the fjord $\left(41^{\circ} 29^{\prime} \mathrm{S}, 72^{\circ} 18^{\prime} \mathrm{W}\right)$. Sampling was initially performed monthly beginning in January. Dominance of Prorocentrum micans was observed on 8 March. Samples of this bloom were then taken every $3 \mathrm{~d}$ until 29 March to follow the dynamics of the infections of P. micans by Amoebophrya spp. This sampling frequency was selected considering both the average daily growth rate of dinoflagellates $\left(0.3 \mathrm{~d}^{-1}\right.$; Smayda 1997) and the generation time of Amoebophrya spp. (2 to 3 d, Coats \& Park 2002).

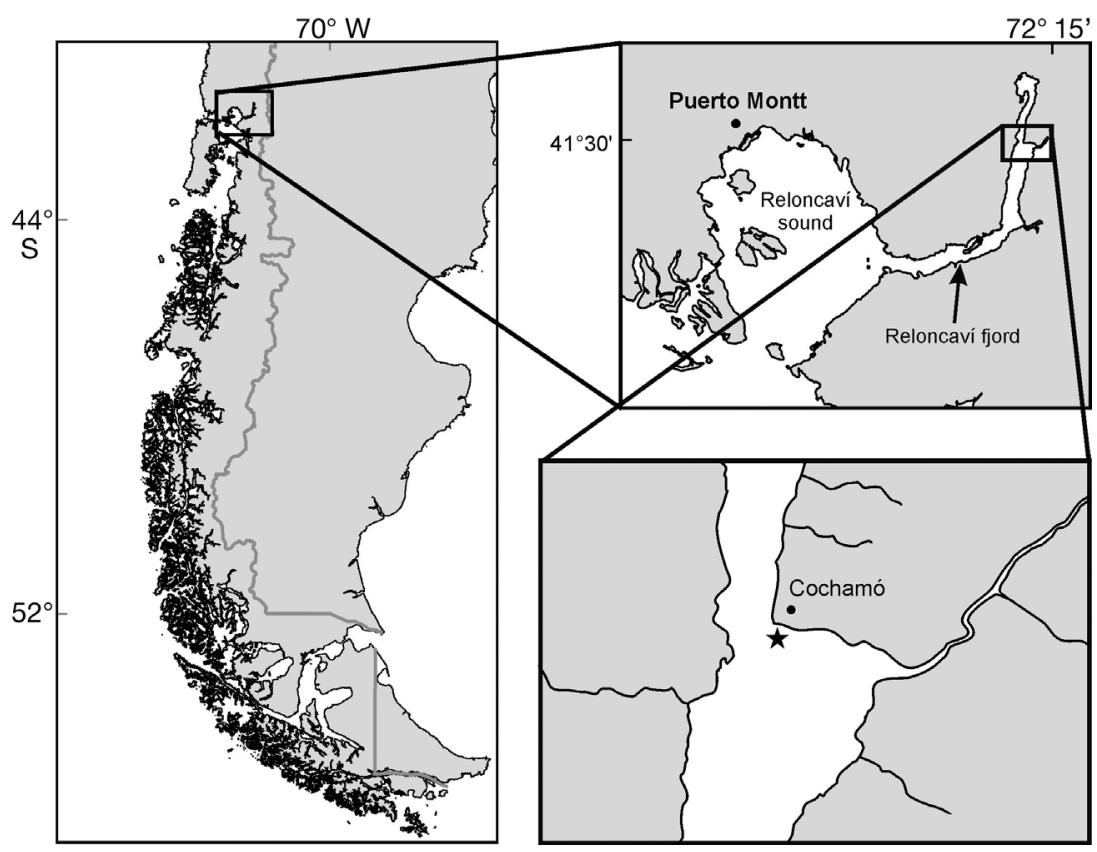

Fig. 1. Sampling station ( $\star$ ) in Reloncaví Fjord, southern Chile
CTD (Sea Bird 19-plus) casts were used to obtain in situ vertical profiles of salinity, temperature, and fluorescence. Five depths were then selected for sampling. These depths were positioned (1) at the subsurface, (2) above and (3) below the pycnocline, (4) at the fluorescence maximum, and (5) at $16 \mathrm{~m}$. Samples for phytoplankton, Amoebophryidae, chlorophyll a (chl a), and macronutrient analyses were collected in 3 replicates using a submergible pump (Rule 800 GPH).

\section{Macronutrients and chl a}

Water samples to determine macronutrient concentrations $\left(\mathrm{NO}_{3}, \mathrm{PO}_{4}, \mathrm{Si}(\mathrm{OH})_{4}\right)$ were collected in $50 \mathrm{ml}$ polyethylene bottles and kept frozen $\left(-20^{\circ} \mathrm{C}\right)$ until analysis using colorimetric procedures (Strickland \& Parsons 1972). Water samples (50 ml) for $\mathrm{chl} \mathrm{a}$ determination were filtered onto Whatman GF/F glass-fiber filters and frozen at $-20^{\circ} \mathrm{C}$ until analysis. Chl a was extracted overnight in acetone (90\%) and measured with a digital fluorometer (Turner Design Model PS-700), and its concentration ( $\mu g \mathrm{l}^{-1}$ ) was determined using the equation recommended by Parsons et al. (1984).

\section{Phytoplankton counting}

Samples were immediately fixed with Lugol's solution, and quantifications were performed using the Utermöhl (1958) method under an inverted microscope (Nikon Eclipse TS100) after sedimentation in $10 \mathrm{ml}$ columns. Units (cells or colonies) were quantified in random fields (Uhelinger 1964) under 20× magnification until at least 100 units $(p<0.05)$ were enumerated (Lund et al. 1958). For the rare species, the whole bottom of the chamber was examined at a magnification of $40 \times$.

\section{Amoebophryidae detection}

To enumerate the Amoebophryidae dinospores and calculate Amoebophrya spp. prevalence (\% of infected dinoflagellate hosts), $250 \mathrm{ml}$ aliquots of seawater were immediately fixed after sampling with paraformaldehyde (1\% final concentration), stored for $1 \mathrm{~h}$ 
in the dark at $4^{\circ} \mathrm{C}$, and filtered onto $0.8 \mu \mathrm{m}$ polycarbonate filters (25 $\mathrm{mm}$ diameter) with a vacuum pump $(<200 \mathrm{~mm} \mathrm{Hg})$. The filters were then dehydrated through an ethanol series $(50,80$, and $100 \% ; 3 \mathrm{~min}$ each), dried briefly at room temperature, and stored at $-80^{\circ} \mathrm{C}$. The different Amoebophryidae life stages were detected by fluorescent in situ hybridization coupled with tyramide signal amplification (FISHTSA) using the ALV01 oligonucleotide probe (5'GCC TGC CGT GAA CAC TCT-3') specific for Amoebophryidae (Chambouvet et al. 2008) labeled with horseradish peroxidase (Thermofisher). The FISH procedure was performed as described by Siano et al. (2011). After hybridization, the filters were covered with calcofluor (for visualization of dinoflagellate theca; $100 \mathrm{ng} \mathrm{ml}^{-1}$ ) for $10 \mathrm{~min}$ and washed in distilled water. Then, they were mounted using antifading reagent (AF1, Citifluor) with propidium iodide (for recognition of nuclei; $10 \mu \mathrm{g} \mathrm{ml}^{-1}$ ) and stored at $4^{\circ} \mathrm{C}$ until analysis.

All hybridized and stained filters were observed with an Olympus BX-51 epifluorescence microscope equipped with a 11012v2-Wide Blue filter set (ChromaTechnology) and a CCD camera (Spot-RT, Diagnostic Instruments). Cells were observed with fluorescence filter sets for calcofluor (excitation: $345 \mathrm{~nm}$; emission: $455 \mathrm{~nm}$ ), propidium iodide (excitation: $536 \mathrm{~nm}$; emission: $617 \mathrm{~nm}$ ), and fluorescein tyramide (excitation: $495 \mathrm{~nm}$; emission: $520 \mathrm{~nm}$ ). Amoebophryidae dinospores were counted at $1000 \times$ magnification in 20 randomly chosen microscopic fields. To estimate the prevalence of Amoebophrya spp. (\% of infected hosts), dinoflagellates were counted at $20 \times$ or $40 \times$ magnification on the whole surface of the piece of filter. A specimen was considered infected when the nucleus of the parasitoid together with the probe signal were clearly identifiable in the host cell. Prevalences were considered reliable when at least 50 specimens of each dinoflagellate species were observed. Host mortality induced by Amoebophrya, i.e. the percentage of hosts killed per day, was estimated according to Coats \& Bockstahler (1994):

Host mortality $=\frac{\text { Amoebophrya prevalence }}{\text { Amoebophrya generation time }}$

A generation time of $2 \mathrm{~d}$ was determined for Amoebophrya at $20^{\circ} \mathrm{C}$ under culture conditions (Yih \& Coats 2000, Coats \& Park 2002). This was adjusted to $2.85 \mathrm{~d}$ considering the average ambient temperature $\left(15^{\circ} \mathrm{C}\right)$ observed during this study and a $\mathrm{Q}_{10}$ of 2 (Montagnes et al. 2008).

To estimate the importance of Amoebophryacaused mortality for the decrease of a Prorocentrum micans bloom, the in situ growth rate $(\mu)$ of this dinoflagellate species was estimated assuming exponential growth (Guillard 1973):

$$
\mu=\frac{1}{t_{2}-t_{1}} \ln \frac{N_{2}}{N_{1}}
$$

where $\mu$ is the growth rate $\left(\mathrm{d}^{-1}\right)$, and $N_{1}$ and $N_{2}$ were the abundances of $P$. micans on $8\left(t_{1}\right)$ and 17 March $\left(t_{2}\right)$, respectively.

\section{Statistical analysis}

The monthly temporal distribution of phytoplankton assemblages related to nutrient concentrations was evaluated by a canonical correspondence analysis (CCA) using CANOCO 4.5 software (ter Braak 1995). Data from sampling performed on 10 January, 14 February, and 8 and 26 March were previously transformed logarithmically $(\ln [x+1])$ and organized in a 'biological' matrix that included the abundance of species present in at least $10 \%$ of the samples and an 'explanatory' matrix including concentrations of silicic acid, nitrate, and orthophosphate ( $\mathrm{n}=60$ ). Monte Carlo permutation testing (500 permutations, CANOCO 4.5) was used to determine the significance of the variables and the first 2 ordination axes.

The effect of nutrients on the short-term temporal dynamics of phytoplankton was assessed by Spearman correlation analyses (Statistica 6.0). Given the expectation of a time delay between the increase of nutrients and the phytoplankton growth response (Huppert et al. 2002), the abundances of predominant species observed at each sampling date between 11 and 29 March were correlated with the respective nutrient concentrations measured on the previous sampling date (between 8 and 26 March). Due to the strong vertical stratification usually observed in Reloncaví Fjord, correlations were established separately for each depth $(\mathrm{n}=24)$ to minimize the interference of light and salinity related to the vertical variability of these variables. Similarly, because a time-delay is also expected to occur in hostparasitoid dynamics (Montagnes et al. 2008, Salomon \& Stolte 2010), short-term interactions between Prorocentrum micans and parasitoids belonging to the Amoebophryidae were evaluated by correlating depth-integrated $P$. micans abundances from each sampling with depth-integrated numbers of dinospores and infected $P$. micans observed on the previous sampling date $(\mathrm{n}=24)$. Infected $P$. micans abundances were based on the prevalence estimated by FISH and the total P. micans enumerated in Lugol- 
stained samples. For all analyses, data were logarithmically transformed $(\ln [x+1])$.

\section{Amoebophryidae genetic analysis}

Samples were taken by net hauling $(25 \mu \mathrm{m}$ pore size), filtered through an $80 \mu \mathrm{m}$ mesh, and stored in ethanol $(99 \%)$ at $-20^{\circ} \mathrm{C}$. Genetic characterization of parasitoids belonging to the Amoebophryidae was based on 5 samples obtained on 10 January, 14 February, and 8, 11, and 14 March (environmental sequences). For each sample, $100 \mu \mathrm{l}$ of $25 \mu \mathrm{m}$ net samples were transferred to $500 \mu \mathrm{l}$ tubes. After centrifugation ( $15 \mathrm{~min}$ at $14000 \mathrm{~g}$ at $4^{\circ} \mathrm{C}$ ), the volume was adjusted to $10 \mu$ l. Additionally, infected dinoflagellate cells bearing a mature Amoebophrya trophont were individually sorted using a glass micropipette and transferred to a $500 \mu \mathrm{l}$ tube. Two infected Prorocentrum micans cells collected in the Concarneau Bay (northwestern coast of France, Atlantic Ocean) on 17 May 2011 were also sequenced. DNA was extracted using a modified guanidinium isothiocyanate protocol (Chomczynski \& Sacchi 2006) as described by Alves-de-Souza et al. (2011). Extraction products were used for PCR amplifications using GoTaq DNA polymerase (Promega). For environmental sequences, the SSU rDNA gene was amplified using the probe ALV01 as forward primer (5'AGA GTG TTC ACG GCA GGC-3') and the general eukaryotic primer $1055 \mathrm{R}$ as reverse $\left(5^{\prime}\right.$-ACG GCC ATG CAC CAC CAC CCA T-3'). For isolated cells, sequences were obtained using ALV01 as forward primer and 1818R as reverse (5'-ACG GAA ACC TTG TTA CG-3'). The PCR program included a denaturation step $\left(95^{\circ} \mathrm{C}\right.$ for $\left.5 \mathrm{~min}\right)$, followed by 35 cycles of denaturation $\left(1 \mathrm{~min}\right.$ at $\left.95^{\circ} \mathrm{C}\right)$, hybridization $\left(45 \mathrm{~s}\right.$ at $\left.55^{\circ} \mathrm{C}\right)$, and elongation $\left(1 \mathrm{~min} 15 \mathrm{~s}\right.$ at $\left.72^{\circ} \mathrm{C}\right)$. The final elongation step lasted $7 \mathrm{~min}$ at $72^{\circ} \mathrm{C}$. PCR products were cloned using the TOPO TA Cloning ${ }^{\circledR}$ kit (Invitrogen) according to manufacturer's recommendations, and selected clones were amplified by PCR following the protocol described above. PCR products were purified using the ExoSAP-IT kit (USB) following the manufacturer's recommendations and directly sequenced on an ABI Prism 3100 automatic sequencer (Applied Biosystems). The KeyDNAtools software (http://keydnatools.com) was used to remove chimeras and to assign the obtained sequences to MALV II clades as defined by Guillou et al. (2008).

Available sequences were aligned using the online package MAFFT version 6 (http://mafft.cbrc.jp/ alignment/software/index.html). Environmental sequences $<699 \mathrm{bp}$ were not considered for phylogeny. The best nucleotide substitution model was determined using MEGA5 (Tamura et al. 2011), and a general time-reversible model was selected with a gamma distribution and invariant sites. Maximum likelihood was measured using MEGA5, and the robustness of the inferred topology was supported by bootstrap resampling (500 replicates). Gaps and missing data were completely deleted. Perkinsozoa sequences (Parvilucifera spp. and Perkinsus spp.) were used as outgroups (GenBank accession nos. X75762, AY487833, AF133909, and EU502912). The sequences obtained during this study were deposited in GenBank (accession nos. JN998202-JN998312 and JQ038241; Appendix 1).

\section{RESULTS}

\section{Characteristics of the sampling period}

The near-surface water column (0-16 m) was characterized by a 2-layer structure during the whole sampling period: the upper layer was characterized by low salinities (0.6-16) and high temperatures $\left(14-18^{\circ} \mathrm{C}\right)$ and the lower layer by higher salinities $(24-32)$ and lower temperatures $\left(11-14.5^{\circ} \mathrm{C}\right)$. The result was a strongly stratified water column with a pronounced pycnocline located at 5 to $8 \mathrm{~m}$ (Fig. 2a,b). Strong vertical distribution was also observed for nutrients (Fig. 2c-e). The upper layer was characterized by higher concentrations of $\mathrm{Si}(\mathrm{OH})_{4}(20-102 \mu \mathrm{M})$, whereas the lower layer generally had higher values of $\mathrm{NO}_{3}(6-17 \mu \mathrm{M})$ and $\mathrm{PO}_{4}(0.5-2 \mu \mathrm{M})$. The highest values of $\mathrm{Si}(\mathrm{OH})_{4}$ and $\mathrm{NO}_{3}$ were observed at the beginning of the sampling period in January (at 2 to 3 and $12 \mathrm{~m}$, respectively), and the lowest concentrations were detected on 14 February and 11 March. After $20 \mathrm{March}, \mathrm{Si}(\mathrm{OH})_{4}$ (up to $56 \mu \mathrm{M}$ ) slowly increased in the upper layer, whereas $\mathrm{PO}_{4}$ reached the highest concentrations observed during this study (up to $3 \mu \mathrm{M})$ at all depths.

Fluctuations of chl a corresponded to different phytoplanktonic assemblages (Fig. $3 \mathrm{a}-\mathrm{C}$ ). The beginning of the study was characterized by moderate chl a concentrations, with a peak observed on 10 January at $8 \mathrm{~m}\left(6.6 \mu \mathrm{g} \mathrm{l}^{-1}\right)$ dominated by the diatom Lepto-

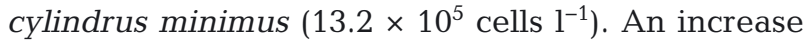
in phytoplankton biomass was observed in the subsequent months, with similar chl a concentrations observed on 14 February and 8 March $\left(\sim 12 \mu \mathrm{g} \mathrm{l}^{-1}\right)$ at 8 and $12 \mathrm{~m}$, respectively. However, the specific compo- 


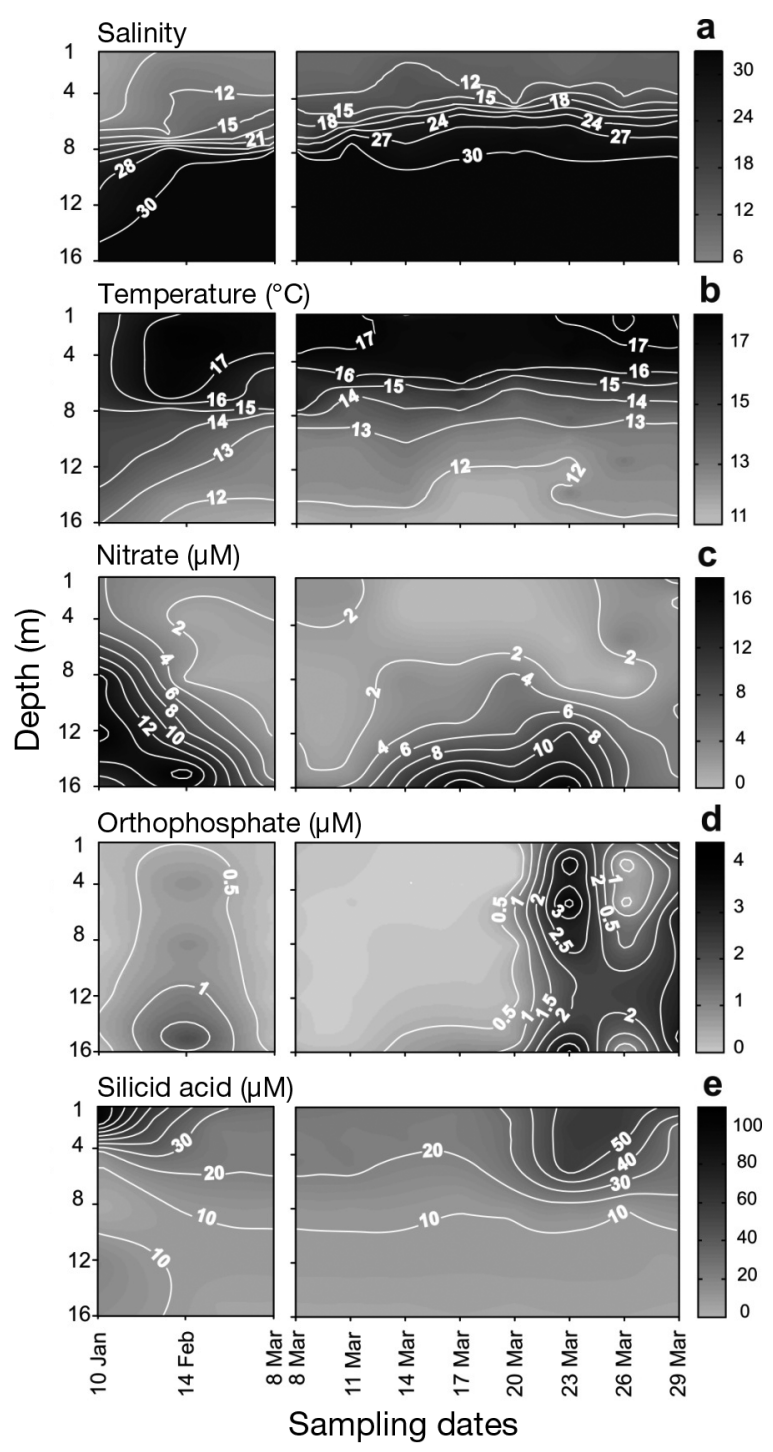

Fig. 2. Vertical and temporal distribution of (a) salinity, (b) temperature $\left({ }^{\circ} \mathrm{C}\right)$, (c) nitrate $\left(\mathrm{NO}_{3} ; \mu \mathrm{M}\right)$, (d) orthophosphate $\left(\mathrm{PO}_{4} ; \mu \mathrm{M}\right)$, and (e) dissolved silicate $\left(\mathrm{Si}(\mathrm{OH})_{4} ; \mu \mathrm{M}\right)$ at the sampling station in Reloncaví Fjord during the austral summer 2009

sition observed on these 2 sampling dates was drastically different. A small centric diatom $(<5 \mu \mathrm{m})$ was the predominant species on 14 February $\left(22.2 \times 10^{5}\right.$ cells $\mathrm{l}^{-1}$ at $8 \mathrm{~m}$ ), whereas the dinoflagellate Prorocentrum micans $\left(10.3 \times 10^{4}\right.$ cells l$^{-1}$ at $\left.12 \mathrm{~m}\right)$ dominated the phytoplankton community on 8 March. The detection of this dinoflagellate bloom started the high frequency sampling period. The $P$. micans abundance drastically decreased from 8 to 14 March $\left(<1 \times 10^{4}\right.$ cell $^{-1}$ at all depths; Fig. 3c). From 14 to 20 March, chl a values were the lowest observed during the monitoring survey $\left(>4 \mu \mathrm{g} \mathrm{l}^{-1}\right)$, with phytoplankton assemblages mainly composed of the diatoms

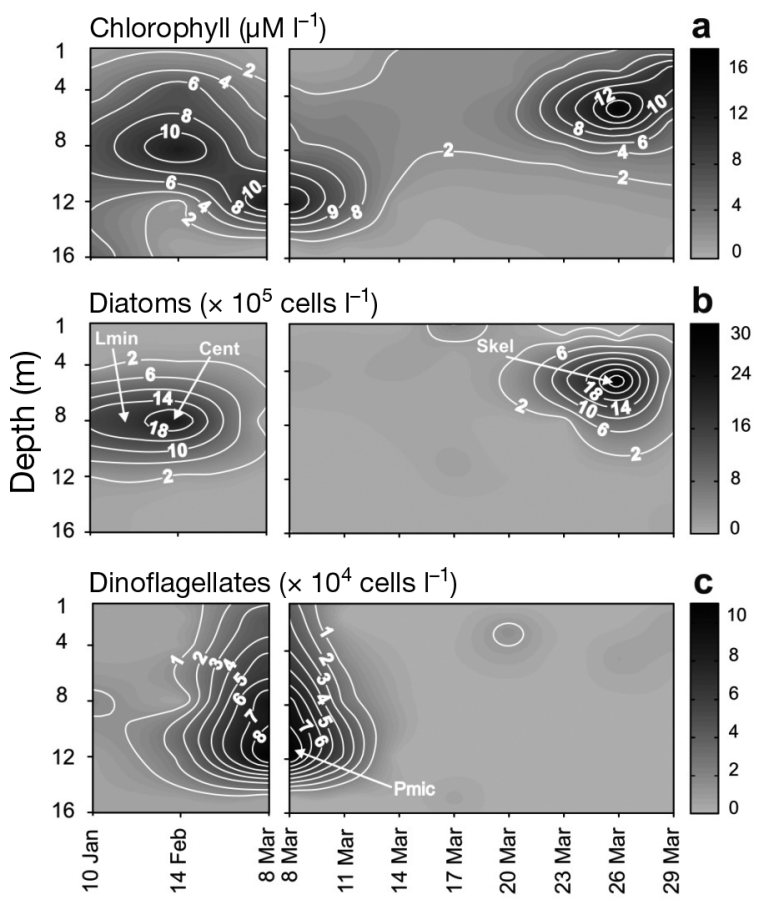

Sampling dates

Fig. 3. Temporal and vertical distribution of (a) chlorophyll a $\left(\mu \mathrm{g}^{-1}\right)$ and abundances of (b) diatoms $\left(\times 10^{5}\right.$ cells $\left.^{-1}\right)$ and (c) dinoflagellates $\left(\times 10^{4}\right.$ cells $\left.^{-1}\right)$. Peaks of most abundant species are indicated by arrows. Lmin: Leptocylindrus minimus, Cent: small unidentified centric diatom, Skel: Skeletonema spp., Pmic: Prorocentrum micans

Skeletonema spp. ( $>4$ cells $\times 10^{5}$ cells $\left.1^{-1}\right)$ and Thalassionema nitzschioides $\left(<0.5 \times 10^{5}\right.$ cells $\left.1^{-1}\right)$. Finally, the strong increase of chl a $\left(16.5 \mu \mathrm{g} \mathrm{l}^{-1}\right)$ culminating on 26 March at $5 \mathrm{~m}$ was mainly induced by a bloom

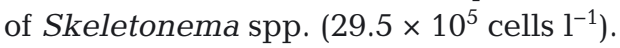

The importance of nutrients on the overall composition of phytoplankton assemblages during the study was assessed by the CCA analysis applied to data collected on 10 January, 14 February, and 8 and 26 March. Together, the eigenvalues of the first 2 canonical axes (0.107 and 0.074, respectively) accounted for $77.5 \%$ of the total variance. Species and nutrients showed correlation values of 0.77 and 0.64 on the canonical Axes 1 and 2, respectively. The compositional Axis 1 (SPECIES AXIS 1) was correlated mainly with $\mathrm{PO}_{4}(0.74)$, whereas $\mathrm{Si}(\mathrm{OH})_{4}(0.40)$ and $\mathrm{NO}_{3}$ $(0.32)$ were correlated with the compositional Axis 2 (SPECIES AXIS 2), both axes being statistically significant (Monte Carlo testing, $p=0.002$ ). The forward stepwise model indicates that these 3 nutrients were statistically significant $(p=0.002)$. The ordination diagram with the scores obtained is shown in Fig. 4. On Axis 1, the small centric diatom was positively correlated with $\mathrm{PO}_{4}$ concentration, whereas on Axis 2, Leptocylindrus minimus and Skeletonema spp. were pos- 


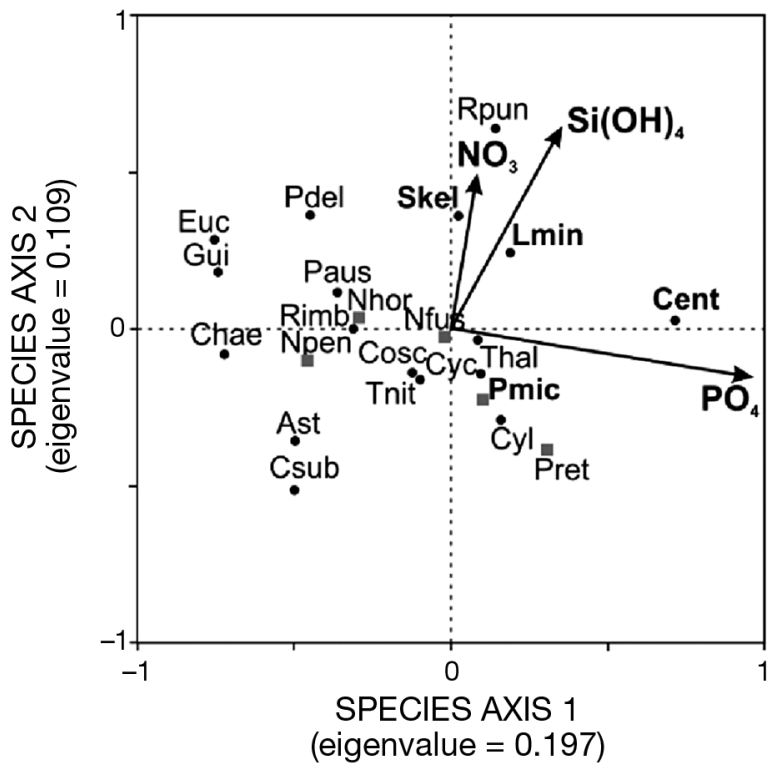

Fig. 4. Ordination diagram with the scores of species obtained in the canonical correspondence analysis related to nutrient vectors (based on data obtained on 10 January, 14 February, and 8 and $26 \mathrm{March}) . \mathrm{NO}_{3}$ : nitrate, $\mathrm{Si}(\mathrm{OH})_{4}$ : dissolved silicate acid, $\mathrm{PO}_{4}$ : orthophosphate. @: diatoms, $\square$ : dinoflagellates. Most abundant species during the study in bold. Ast: Asteromphalus sp., Cent: small unidentified centric diatom, Cosc: Coscinodiscus spp., Csub: Chaetoceros subtilis, Chae: Chaetoceros spp., Cyc: Cyclotella sp., Cyl: Cylindrotheca closterium, Euc: Eucampia sp., Gui: Guinardia delicatissima, Lmin: Leptocylindrus minimus, Pdel: Pseudo-nitzschia spp. group delicatissima, Paus: Pseudonitzschia spp. group australis, Rimb: Rhizosolenia imbricata, Rpun: Rhizosolenia pungens, Skel: Skeletonema, Thal: Thalassiosira spp., Tnit: Thalassionema nitzschioides, Nfus: Neoceratium fusum, Nhor: Neoceratium horridum, Npen: Neoceratium pentagonum, Pmic: Prorocentrum micans, Pret: Protoceratium reticulatum

itively correlated with $\mathrm{NO}_{3}$ and $\mathrm{Si}(\mathrm{OH})_{4}$. Prorocentrum micans was also distributed on Axis 2, although it was not related to any environmental variable. For the high-frequency sampling period (8 to $29 \mathrm{March}$ ), a Spearman correlation analysis showed that Skeletonema spp. abundances were positively correlated both with the $\mathrm{Si}(\mathrm{OH})_{4}(\mathrm{R}=0.52, \mathrm{p}=0.01)$ and $\mathrm{PO}_{4}(\mathrm{R}=$ $0.73, p<0.001$ ) levels observed $3 \mathrm{~d}$ before. However, no correlation was detected between the demise of $P$. micans and variation of $\mathrm{NO}_{3}$ and $\mathrm{PO}_{4}$ concentrations.

\section{Infections by Amoebophryidae parasitoids}

Infections, revealed by the general oligonucleotidic probe ALV01 specific for Amoebophryidae, were restricted to dinoflagellates. From a total of 12 recorded dinoflagellate taxa, only Dinophysis acumi- nata, Phalacroma rotundata, and Prorocentrum micans were infected by parasitoids belonging to the Amoebophryidae (Table 1). Different life-cycle stages of parasitoids were detected by FISH using the probe ALV01 but only at depths below the halocline (Figs. $5 \& 6)$. Dinospores $(2-3 \mu \mathrm{m})$ were characterized by a dense nucleus occupying a large part of the cell volume (Fig. 5a). Early infections were detected in close association with the host nucleus (Fig. $5 b-d$ ). Mature trophonts showed a typical beehive configuration (Fig. 5d,f,g), indicating their affiliation to the genus Amoebophrya.

Infections of Dinophysis acuminata and Phalacroma rotundata were observed on 10 January and 14 February, with the highest prevalence $(10 \%)$ recorded on $D$. acuminata on the first sampling date. Infections of Prorocentrum micans were observed on $8 \mathrm{March}$, with relatively low prevalence values $(2 \%)$ observed at $12 \mathrm{~m}$, together with the maximal abundance of $P$. micans (Fig. 6). An increase in prevalence was observed during the 6 subsequent days and was associated with the rapid $P$. micans bloom demise, a

Table 1. Depth-integrated abundances $\left(\times 10^{4}\right.$ cells $\left.\mathrm{m}^{-2}\right)$ of infected and non-infected dinoflagellate species at Reloncaví Fjord on 10 January, 14 February, and 8 March 2009. Amoebophrya spp. prevalence (\% of infected cells) as detected by oligonucleotide probe ALV01 is shown in parentheses

\begin{tabular}{|c|c|c|c|}
\hline & 10 January & 14 February & $8 \mathrm{March}$ \\
\hline \multicolumn{4}{|c|}{ Infected dinoflagellates } \\
\hline $\begin{array}{l}\text { Dinophysis } \\
\text { acuminata }\end{array}$ & $\begin{array}{c}0.012 \\
(10 \% ; \mathrm{n}=55)\end{array}$ & $\begin{array}{c}0.020 \\
(2 \% ; \mathrm{n}=60)\end{array}$ & $\begin{array}{c}0.019 \\
(0 \% ; \mathrm{n}=100)\end{array}$ \\
\hline $\begin{array}{l}\text { Phalachroma } \\
\text { rotundata }\end{array}$ & $\begin{array}{c}0.001 \\
(>1 \% ; \mathrm{n}=20)\end{array}$ & $\begin{array}{c}0.002 \\
(0 \% ; \mathrm{n}=30)\end{array}$ & $\begin{array}{c}0.001 \\
(0 \% ; \mathrm{n}=25)\end{array}$ \\
\hline $\begin{array}{l}\text { Prorocentrum } \\
\text { micans }\end{array}$ & $\begin{array}{c}2.316 \\
(0 \% ; n=50)\end{array}$ & $\begin{array}{c}51.824 \\
(0 \% ; \mathrm{n}=105)\end{array}$ & $\begin{array}{c}87.339 \\
(2 \% ; \mathrm{n}=102)\end{array}$ \\
\hline \multicolumn{4}{|c|}{ Other dinoflagellates } \\
\hline $\begin{array}{l}\text { Neoceratium } \\
\text { fusum }\end{array}$ & 0.340 & 0.049 & 0.043 \\
\hline $\begin{array}{l}\text { Neoceratium } \\
\text { horridum }\end{array}$ & 0.020 & 0.002 & 0.051 \\
\hline $\begin{array}{l}\text { Neoceratium } \\
\text { pentagonum }\end{array}$ & 0.140 & 0.008 & 0.026 \\
\hline $\begin{array}{l}\text { Dinophysis } \\
\text { circularis }\end{array}$ & 0.000 & 0.002 & 0.008 \\
\hline $\begin{array}{l}\text { Dinophysis } \\
\text { tripos }\end{array}$ & 0.000 & 0.012 & 0.002 \\
\hline $\begin{array}{r}\text { Dissodinium } \\
\text { semilunula }\end{array}$ & 0.220 & 0.008 & 0.003 \\
\hline $\begin{array}{l}\text { Protoceratium } \\
\text { reticulatum }\end{array}$ & 0.000 & 0.295 & 0.226 \\
\hline $\begin{array}{l}\text { Pyrophacus } \\
\text { horologium }\end{array}$ & 0.000 & 0.088 & 0.049 \\
\hline $\begin{array}{l}\text { Scrippsiella } \\
\text { cf. trochoidea }\end{array}$ & 0.000 & 0.000 & 0.128 \\
\hline
\end{tabular}



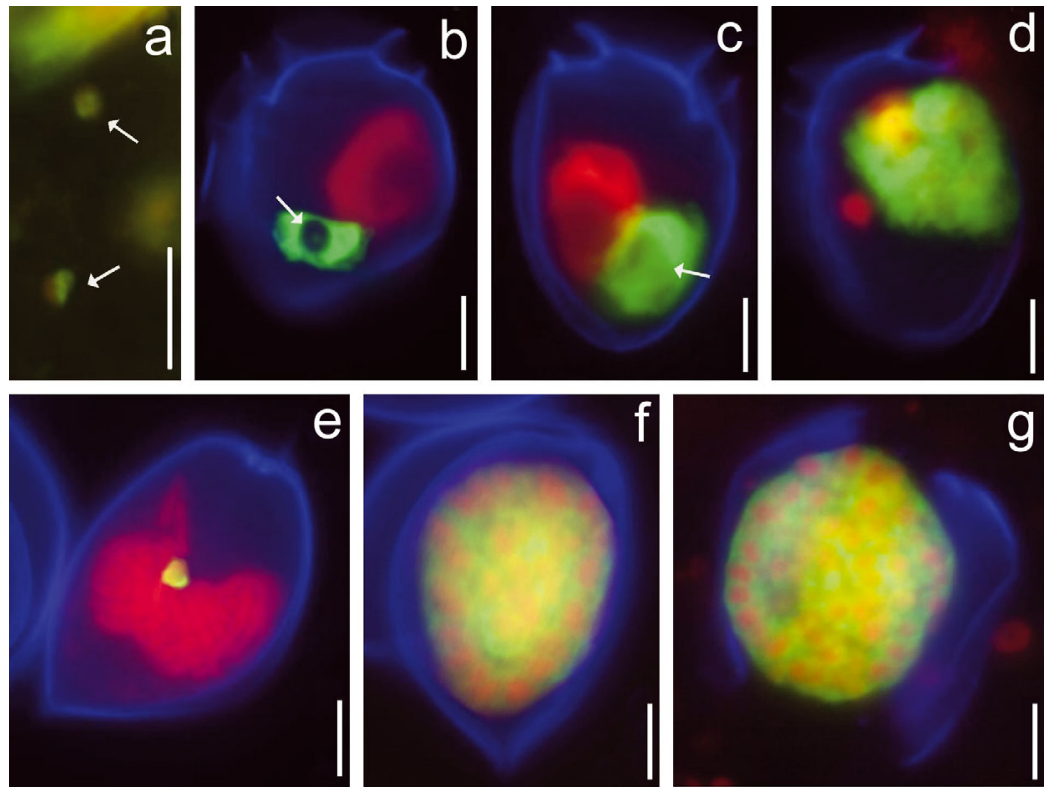

Fig. 5. Amoebophrya spp. life-cycle stages as detected by fluorescence in situ hybridization. Cell nucleus (red), dinoflagellate theca (blue), and fluorescence of probe ALV01 targeting Amoebophrya SSU ribosomal RNA (green) are shown. (a) Dinospores (arrows), (b) initial infection in Dinophysis acuminata nucleus, (c,d) intermediate infection in Dinophysis acuminata showing an incipient mastigocoel (arrows in b,c), (e) initial infection in Prorocentrum micans nucleus, and (f,g) final infection showing a mature trophont occupying the entire intracellular space of $P$. micans. Scale bars $=10 \mu \mathrm{m}$

greater number of infected cells on 11 March $(0.47 \times$

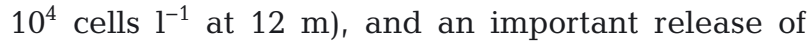
dinospores on 14 March $\left(16.8 \times 10^{5}\right.$ cells $^{-1}$ at $\left.12 \mathrm{~m}\right)$. The highest prevalence (12\%) was observed on 17 March at $12 \mathrm{~m}$. From 14 March, P. micans was always detectable at relatively low abundances (equivalent to values observed during the 2 first samplings) until the end of the study. The Spearman correlation analysis showed that the dinospore abundances on each sampling date were positively correlated with the numbers of infected cells observed $3 \mathrm{~d}$ before ( $\mathrm{R}$ $=0.93, \mathrm{p}<0.001)$. The estimated host mortalities due to Amoebophrya spp. were $0.7,3.4,4.2$, and $4.5 \%$ on $8,11,14$, and 17 March, respectively. On average, Amoebophrya spp. killed $\sim 3.2 \%$ of the $P$. micans population each day (i.e. $-0.032 \mathrm{~d}^{-1}$ ). Considering a decrease of $-0.31 \mathrm{~d}^{-1}$ in $P$. micans abundance during the same period, we estimated that Amoebophrya spp. accounted for $\sim 10 \%$ of the total P. micans mortality between 8 and 17 March.

Single-cell PCR amplifications indicated that parasitoids belonging to Amoebophryidae parasitoids infecting Dinophysis acuminata (6 clones obtained from 2 individuals isolated in January), Phalacroma rotundata (5 clones obtained from 2 individuals isolated on 10 January), and Prorocentrum micans (1 clone resulting from 1 individual isolated on 8 March) belonged to the MALV II Clade 4, according to the classification proposed by Guillou et al. (2008) (see Appendix 1). A total of 96 environmental sequences belonging to the Amoebophryidae were obtained from the DNA extracted on 10 January, 14 February, and 8, 11, and 14 March from the planktonic communities $>25 \mu \mathrm{m}$. Most of these sequences belonged to Clade 4 (83 sequences in total); the remaining 13 environmental sequences belonged to Clades 5, 6, and 12 (Guillou et al. 2008). Fig. 7 shows a phylogenetic analysis considering all of the sequences obtained by single-cell PCR and environmental sequences $>699 \mathrm{bp}$. Although environmental sequences belonging to Clades 5 and 12 were not included in the analysis due their short length, their probable position is indicated in the phylogenetic tree. Considering bootstrap values $>70 \%$, sequences belonging to Clade 4 obtained from Reloncaví Fjord during the present study were distributed in 5 sub-clusters. Cluster A included 1 environmental sequence obtained from a sample collected on 10 January and 2 sequences of Amoebophrya spp. infecting Gymnodinium instriatum (AF472554 and HM483394) published by Gunderson et al. (2002) and Coats et al. (2010). Sequences from the infected cells of $D$. acuminata and P. rotundata were affiliated to Sub-clusters B, C, and D. Subcluster E was exclusively formed by environmental sequences retrieved on 14 March and also included 2 sequences of Amoebophrya spp. infecting P. micans (AY208893) and Ceratium tripos (AY208893) published by Kim et al. (2008). Although the 2 infected $P$. micans cells (JN998214 and JQ038241) collected in Concarneau Bay also belonged to Clade 4, they were grouped in a sub-cluster separate from the sequences obtained from Reloncaví Fjord.

\section{DISCUSSION}

\section{Evolution of phytoplankton assemblages}

Prorocentrum micans is a common species in summer phytoplankton assemblages in southern Chile, although it is usually observed at low abundances 


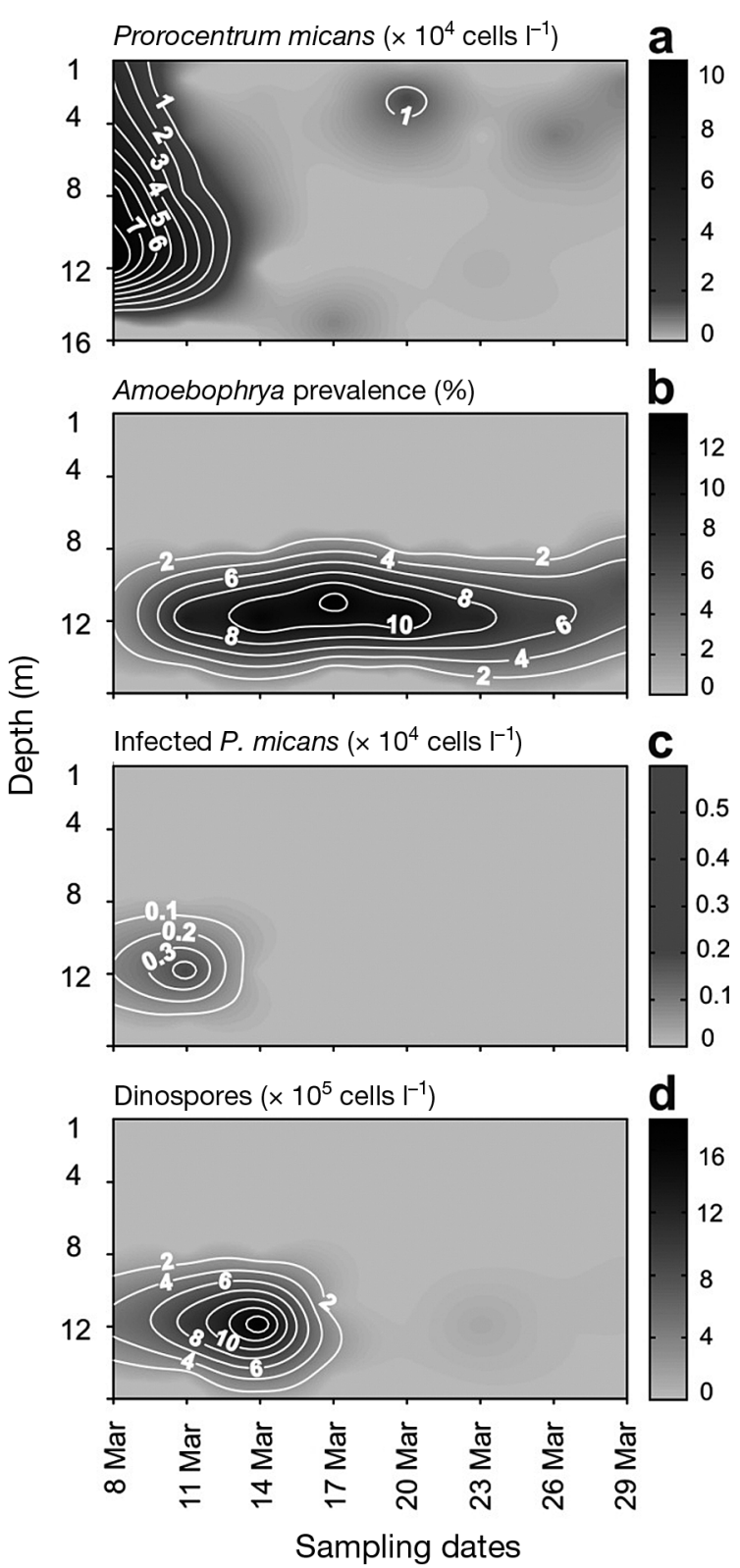

Fig. 6. Vertical and temporal dynamics of infection by parasitoids belonging to the Amoebophryidae on Prorocentrum micans observed between 8 and 29 March 2009. (a) P. micans abundances $\left(\times 10^{4}\right.$ cells $\left.\mathrm{l}^{-1}\right)$, (b) Amoebophrya prevalences (\%) on P. micans (c), number of infected P. micans $\left(\times 10^{4}\right.$

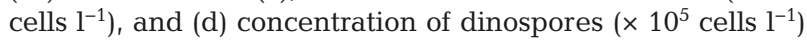

$\left(<100\right.$ cells l$^{-1}$, C. Alves-de-Souza unpubl. data). The last bloom reported in the study area was in March 1983, with relatively high abundances $\left(3.8 \times 10^{7}\right.$ cells $1^{-1}$; Lembeye \& Campodónico 1984) covering an extensive geographical area including Reloncaví Fjord and part of Reloncaví Sound (both indicated in Fig. 1). The magnitude and geographical extension of the P. micans bloom observed in March 2009 was apparently similar to that observed $26 \mathrm{yr}$ before
(A. Clément pers. comm.). Maximum P. micans abundances occurred simultaneously with the lowest $\mathrm{Si}(\mathrm{OH})_{4}$ levels observed during the present study, whereas diatom blooms were positively related to high $\mathrm{Si}(\mathrm{OH})_{4}: \mathrm{NO}_{3}$ periods. The relative concentrations of $\mathrm{Si}(\mathrm{OH})_{4}$ and $\mathrm{NO}_{3}$ have been highlighted as the main factor determining phytoplankton composition in the fjords of southern Chile (Alves-de-Souza et al. 2008, Torres et al. 2011), with low $\mathrm{Si}(\mathrm{OH})_{4}: \mathrm{NO}_{3}$ ratios favoring the development of non-diatom blooms (Iriarte et al. 2001, 2007).

\section{Parasitoid and host diversity}

Although 12 species of dinoflagellates were identified, only 3 (Dinophysis acuminata, Phalacroma rotundata, and Prorocentrum micans) were infected by parasitoids belonging to the Amoebophryidae. Despite that, and taking into account the restricted spatial scale considered in the present study, parasitoids belonging to the Amoebophryidae were genetically diverse, as they were represented by 5 different clades. Clade 5, 6, and 12 are only known from environmental sequences. Sequences belonging to these clades are probably widely distributed (detected to date in the North Sea, the northern French coast, the Indian Ocean, the Sargasso Sea, and the Mediterranean Sea; Guillou et al. 2008). Clade 4 has been reported to infect $P$. micans from Chesapeake Bay, USA (AY208893; Kim et al. 2008), and Concarneau Bay, on the northwestern coast of France (JN998213 and JQ038241). This clade was also reported to infect other dinoflagellate species, such as Alexandrium affine, Ceratium tripos, Ceratium lineatum (AY775284, AY208892, and AY260467; Kim et al. 2008), and Gymnodinium instriatum (AF472554 and HM483394; Gunderson et al. 2002, Coats et al. 2010, respectively). Finally, Clade 1 was also described to infect dinoflagellates such as Heterocapsa rotundata (Chambouvet et al. 2008), Prorocentrum minimum (AY208894), and Karlodinium veneficum (AF472553; Gunderson et al. 2002). From these examples, it seems that the hostspecificity of Amoebophryidae parasitoids was not linked to its genetic filiations based upon the SSU rRNA gene (Gunderson et al. 2002, Kim et al. 2008).

Amoebophrya spp. belonging to Clade 4 were confirmed to infect Dinophysis acuminata, Phalacroma rotundata, and Prorocentrum micans based on singlecell PCR. However, phylogenetic analyses revealed that these host species were, in fact, infected by Amoebophrya spp. belonging to different sub- 


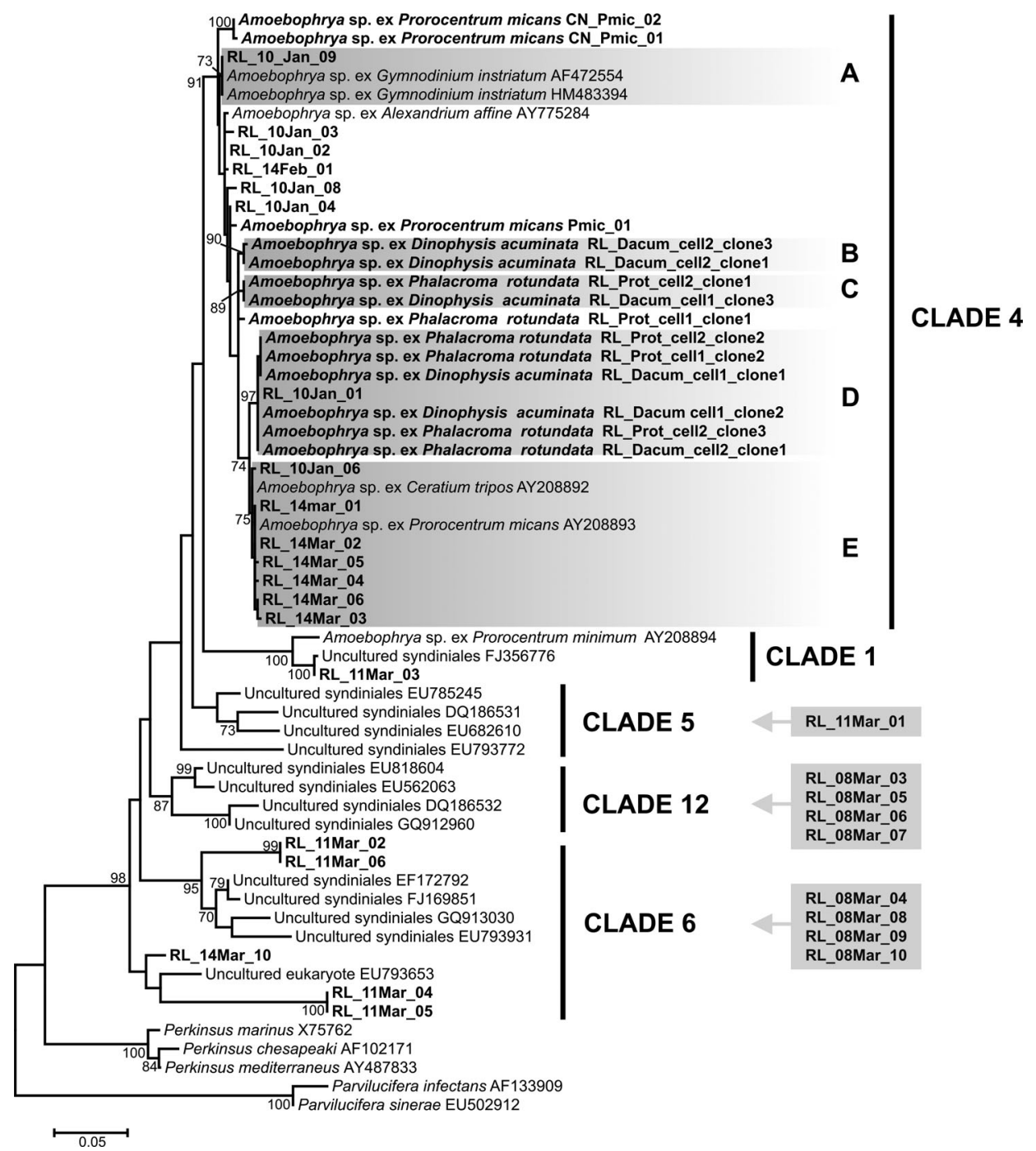

Fig. 7. Phylogeny of parasitoids belonging to the Amoebophryidae using maximum likelihood (ML) analyses of SSU rDNA genes. Sequences obtained in this study are in bold (for GenBank numbers, see Appendix 1). ML bootstrap values ( $>70 \%$ ) are reported at the nodes. Clades 1, 4, 5, 6, and 12 were recognized according to Guillou et al. (2008). Subclusters (A-E) within Clade 4 with bootstrap values $>70 \%$ are highlighted in gray. The probable positions of environmental sequences $<699$ bp belonging to Clades 5, 6, and 12 are indicated by arrows and gray boxes. Scale bar corresponds to $0.05 \%$ divergence

clusters (i.e. different genotypes). Different types of sequences were also obtained from the same host cell, both for $D$. acuminata and $P$. rotundata. Infections in the same dinoflagellate host (Dinophysis norvegica) by Amoebophrya spp. belonging to different genotypes have been previously reported from the Baltic Sea and the North Sea (Salomon et al. 2003). However, this is the first report of different Amoebophrya spp. genotypes infecting the same dinoflagellate individual. Similar results were found by Bachvaroff et al. (2012), who pointed out that individual tintinnid ciliates are frequently infected by different genotypes of Euduboscquella spp. (Syndiniales, MALV Group I). Although parasitoid populations are usually considered to be homogeneous groups, intraspecific genetic diversity determines that some individuals are more aggressive when infecting hosts than others (Combes 2005). This has been demonstrated in culture experiments for the perkinsoid Parvilucifera sinerae infecting the dinoflagellate Alexandrium minutum (Figueroa et al. 2010) and for chytrid fungi infecting freshwater diatoms (Ibelings et al. 2004). Host-parasitoid interactions are characterized by an 'arms race' between host and parasitoid populations, and this, in turn, results in the rapid coevolution between partners and/or cyclic variability in parasitic control (the Red Queen hypothesis; Van Valen 1973). As a consequence, a long coexistence of 
parasitoid and host populations will be reflected in higher intraspecific genetic diversity. This would help to explain, for example, the drastic change in the genetic composition of environmental sequences observed on 8 and 14 March during the present study and the fact that the sequences of Amoebophrya spp. infecting $P$. micans from Reloncaví Fjord and those from other geographic areas were distributed in different sub-clusters.

\section{Host-Amoebophryidae dynamics}

The observed Prorocentrum micans and Amoebophrya dynamic conforms to what has previously been reported for Amoebophryidae (e.g. Coats \& Park 2002, Chambouvet et al. 2008, Salomon \& Stolte 2010). Maximal host abundances were followed by increased parasitoid prevalence and the consequent release of dinospores that reached their maximal density $6 \mathrm{~d}$ after the host peak. This burst of dinospores declined in $3 \mathrm{~d}$, an observation that correlates with the short survival time of dinospores observed in culture (Coats \& Park 2002). Estimations of the host mortality induced by Amoebophrya spp. indicated that $\sim 10 \%$ of the $P$. micans population was killed by these parasitoids between 8 and 17 March. Although this value only partially explains the decrease of $P$. micans abundance observed for the same period (94\%), our results indicate that parasitism by organisms belonging to the Amoebophryidae likely constituted an important loss for its dinoflagellate host during the study period.

The strength of infection by Amoebophrya spp. is often related to the abundance of its dinoflagellate hosts in natural systems (Park et al. 2004). In this sense, the prevalences observed in Dinophysis acuminata and Phalacroma rotundata $(<10 \%)$ were consistent with their low abundances and in accordance with the previous records of Amoebophrya spp. infections of Dinophysis species (Fritz \& Nass 1992, Gisselson et al. 2002, Salomon et al. 2009). However, prevalences were unexpectedly low for Prorocentrum micans, with a maximum of $12 \%$ observed on 17 March. Because P. micans abundances were of the same order of magnitude as during other dinoflagellate blooms in which high Amoebophrya spp. prevalences (30 to $80 \%$ ) have been recorded (Nishitani et al. 1985, Coats et al. 1996, Chambouvet et al. 2008), we expected to find a higher percentage of infected cells during the present study. Nevertheless, culture studies (Yih \& Coats 2000, Coats \& Park 2002) and mathematical simula- tions (Salomon \& Stolte 2010) have demonstrated that the maximal prevalence of Amoebophrya spp. depends on the ratio between host and dinospores rather than host density. Using equations given by Salomon \& Stolte (2010) and considering a generation time of $2.85 \mathrm{~d}$, parasitoid mortality of $0.5 \mathrm{~d}^{-1}$ (Coats \& Park 2002), and the conditions observed on 8 March (parasitoid prevalences, host and dinospore abundances), on 11 March, we should have observed prevalences similar to those found by Chambouvet et al. (2008) for Amoebophrya spp. infecting Alexandrium minutum $(\sim 40 \%)$. Grazing by ciliates on dinospores has been shown to strongly suppress Amoebophrya infections under natural conditions (Johansson \& Coats 2002). Unfortunately, we have no antecedents regarding ciliate abundances during the studied period, but considering that the number of dinospores actually increased from 8 to $11 \mathrm{March}$, it seems that dinospore mortality (by grazing or other sources) was not the main factor determining Amoebophrya spp. success during this $3 \mathrm{~d}$ period. Alternatively, because nutrients can have a positive effect on the infective success and longevity of dinospores under culture conditions (Yih \& Coats 2000), it is possible that low $\mathrm{NO}_{3}$ and $\mathrm{PO}_{4}$ concentrations could have had an adverse effect on the quality of the dinospores produced.

The present study demonstrated for the first time that parasitoids belonging to the Amoebophryidae could be genetically diversified, even in ecosystems where their dinoflagellate hosts are not the predominant phytoplankton group. Although Prorocentrum micans is a common species in southern Chile, it usually occurs at very low abundances, and the formation of blooms is rare. According to Chambouvet et al. (2008), the capacity of parasitoids to control host populations is diminished when the excessive growth of a rare species is stimulated by environmental changes, when resistant host populations may actually be favored. This would be particularly relevant in ecosystems like the Chilean fjords, in which climate changes may favor increased dinoflagellate HABs.

Acknowledgements. We thank B. Hip and J. C. Cabrera for their invaluable help during sampling and in the laboratory. We are also grateful to I. Probert and D. Barriga for their English review of the manuscript and to W. Coats for his insightful comments on the results reported in this paper. This research was partially funded by the Dirección de Investigación y Desarollo (Universidad Austral de Chile; DID-Uach-D-2008), the French National Research Agency (ANR) Aquaparadox ('Biodiversity'), and EC2CO (Microbien, 2009-2010). This work is part of C.A.S.'s PhD thesis. She was financed by a Conicyt doctoral fellowship (Chilean 
government) and by the French ANR Paralex ('The Sixth Extinction'). Additional support for her $\mathrm{PhD}$ thesis was provided by the Centro de Investigación de Ecosistemas de la Patagonia (CIEP).

\section{LITERATURE CITED}

Alves-de-Souza C, González MT, Iriarte JL (2008) Functional groups in marine phytoplankton assemblages dominated by diatoms in fjords of southern Chile. J Plankton Res 30:1233-1243

- Alves-de-Souza C, Cornet C, Nowaczyk A, Gasparini S, Skovgaard A, Guillou L (2011) Blastodinium spp. infect copepods in the ultra-oligotrophic marine waters of the Mediterranean Sea. Biogeosciences 8:2125-2136

> Bachvaroff TR, Kim S, Guillou L, Delwiche C, Coats DW (2012) Molecular diversity of the Syndinian genus Euduboscquella based on single-cell PCR analysis. Appl Environ Microbiol 78:334-345

Cachon J (1964) Contribution à l'étude des péridiniens parasites. Cytologie, cycles évolutifs. Ann Sci Nat Zool 6: $1-158$

Calbet A, Vaqué D, Felipe J, Vila M, Sala MM, Alcaraz M, Estrada M (2003) Relative grazing impact of microzooplankton and mesozooplankton on a bloom of the toxic dinoflagellate Alexandrium minutum. Mar Ecol Prog Ser 259:303-309

Chambouvet A, Morin P, Marie D, Guillou L (2008) Control of toxic marine dinoflagellate blooms by serial parasitic killers. Science 322:1254-1257

Chomczynski P, Sacchi N (2006) The single-step method of RNA isolation by acid guanidinium thiocyanate-phenolchloroform extraction: twenty-something years on. Nat Protoc 1:581-585

Coats DW, Bockstahler KR (1994) Occurrence of the parasitic dinoflagellate Amoebophrya ceratii in Chesapeake Bay populations of Gymnodinium sanguineum. J Eukaryot Microbiol 41:586-593

Coats DW, Park MG (2002) Parasitism of photosynthetic dinoflagellates by three strains of Amoebophrya (Dinophyta): parasite survival, infectivity, generation time, and host specificity. J Phycol 38:520-528

Coats DW, Adam EJ, Gallegos CL, Hedrick S (1996) Parasitism of photosynthetic dinoflagellates in a shallow subestuary of Chesapeake Bay, USA. Aquat Microb Ecol 11:1-9

Coats DW, Kim S, Bachvaroff TR, Handy SM, Delwiche CF (2010) Tintinnophagus acutus n. g., n. sp. (Phylum Dinoflagellata), an ectoparasite of the ciliate Tintinnopsis cylindrica Daday 1887, and its relationship to Duboscquodinium collini Grasse 1952. J Eukaryot Microbiol 57: 468-482

Combes C (2005) The art of being a parasite. The University of Chicago Press, Chicago

> Figueroa RI, Garcés E, Camp J (2010) Reproductive plasticity and local adaptation in the host-parasite system formed by the toxic Alexandrium minutum and the dinoflagellate parasite Parvilucifera sinerae. Harmful Algae 10:56-63

> Fritz L, Nass M (1992) Development of two endoparasitic dinoflagellate Ameobophrya ceratii within host dinoflagellate species. J Phycol 28:312-320

Gisselson LA, Carlsson P, Granéli E, Pallon J (2002) Dinophysis blooms in the deep euphotic zone of the Baltic Sea:
Do they grow in the dark? Harmful Algae 1:401-418

Guillard R (1973) Methods for microflagellates and nannoplankton. In: Stein J (ed) Handbook of phycological methods: culture methods and growth measurements. Cambridge University Press, Cambridge, p 69-85

Guillou L, Viprey M, Chambouvet A, Welsh RM and others (2008) Widespread occurrence and genetic diversity of marine parasitoids belonging to Syndiniales (Alveolata). Environ Microbiol 10:3349-3365

Gunderson JH, John SA, Boman WC, Coats DW (2002) Multiple strains of the parasitic dinoflagellate Amoebophrya exist in Chesapeake Bay. J Eukaryot Microbiol 49: 469-474

Guzmán L, Pacheco H, Pizarro G, Alarcón C (2002) Alexandrium catenella y veneno paralizante de los mariscos en Chile. In: Sar EA, Ferrario ME, Reguera B (eds) Floraciones algales nocivas en el Cono Sur Americano. Instituto Español de Oceanografía, Vigo, p 235-256

Huppert A, Blasius B, Stone S (2002) A model of phytoplankton blooms. Am Nat 159:156-171

Ibelings BW, De Bruin A, Kagami M, Rijkeboer M, Brehm M, Van Donk E (2004) Host parasite interactions between freshwater phytoplankton and chytrid fungi. J Phycol 40: 437-453

- Iriarte JL, Kusch A, Ruiz M (2001) Phytoplankton biomass in the sub-Antarctic area of the Straits of Magellan $\left(53^{\circ} \mathrm{S}\right)$, Chile during spring-summer 1997-1998. Polar Biol 24: 154-162

Iriarte JL, Quiñones L, González RR (2005) Relationship between biomass and enzymatic activity of a bloomforming dinoflagellate (Dinophyceae) in southern Chile $\left(41^{\circ} \mathrm{S}\right)$ : a field approach. J Plankton Res 27:159-166

> Iriarte JL, González HE, Liu KK, Rivas C, Valenzuela C (2007) Spatial and temporal variability of chlorophyll and primary productivity in surface waters of southern Chile (41.5-43 S). Estuar Coast Shelf Sci 74:471-480

Iriarte JL, González HE, Nahuelhual L (2010) Patagonian fjord ecosystems in southern Chile as a highly vulnerable region: problems and needs. Ambio 39:463-466

Johansson M, Coats DW (2002) Ciliate grazing on the parasite Amoebophrya sp. decreases infection of the red-tide dinoflagellate Akashiwo sanguinea. Aquat Microb Ecol 28:69-78

Keane RM, Crawley MJ (2002) Exotic plant invasions and the enemy release hypothesis. Trends Ecol Evol 17: 164-170

- Kim S, Park MG, Kim KY, Kim CH, Yih W, Park JS, Coats DW (2008) Genetic diversity of parasitic dinoflagellates in the genus Amoebophrya and its relationship to parasite biology and biogeography. J Eukaryot Microbiol 55: $1-8$

Lara A, Urrutia R, Luckman BH, Soto D and others (2005) The potential use of tree-rings to reconstruct streamflow and estuarine salinity in the Valdivian Rainforest ecoregion. Dendrochronologia 22:155-161

Lembeye G, Campodónico I (1984) First record bloom of the dinoflagellate Prorocentrum micans. Bot Mar 27:491-493

Lembeye G, Yasumoto T, Zhao J, Fernández R (1993) DSP outbreak in Chilean Fjords. In: Smayda TJ, Shimizu Y (eds) Toxic phytoplankton blooms in the sea. Elsevier, Amsterdam, p 525-529

Lund JWG, Kipling C, Lecren ED (1958) The inverted microscope method of estimating algal number and the statistical basis of estimating by counting. Hydrobiologia 11: 143-170 
Maranda L (2001) Infection of Prorocentrum minimum (Dinophyceae) by the parasite Amoebophrya sp. (Dinoflagellea). J Phycol 37:245-248

Molinet C, Lafon A, Lembeye G, Moreno C (2003) Spatial and temporal distribution patterns of blooms of Alexandrium catenella (Whedon \& Kofoid) Balech 1985, on inland seas of northwest Patagonia, Chile (in Spanish with English Abstract). Rev Chil Hist Nat 76:681-698

Montagnes DJS, Chambouvet A, Guillou L, Fenton A (2008) Responsibility of microzooplankton and parasite pressure for the demise of toxic dinoflagellate blooms. Aquat Microb Ecol 53:211-225

Nishitani L, Erickson G, Chew KK (1985) Role of the parasitic dinoflagellate Amoebophrya ceratii in control of Gonyaulax catenella populations. In: Anderson DM, White AW, Baden DG (eds) Toxic dinoflagellates. Elsevier, New York, NY, p 225-232

Park MG, Yih W, Coats DW (2004) Parasites and phytoplankton, with special emphasis on dinoflagellate infections. J Eukaryot Microbiol 51:145-155

Parsons TR, Maita Y, Lalli CM (1984) A manual of chemical and biological methods for seawater analysis. Pergamon Press, Oxford

Rebolledo L, Lange C, Figueroa D, Pantoja S, Muñoz P, Castro R (2005) 20th century fluctuations in the abundance of siliceous microorganisms preserved in the sediments of the Puyuhuapi channel. Rev Chil Hist Nat 78:469-488

Salomon PS, Stolte W (2010) Predicting the population dynamics in Amoebophrya parasitoids and their dinoflagellate hosts using a mathematical model. Mar Ecol Prog Ser 419:1-10

Salomon PS, Janson S, Granéli E (2003) Multiple species of the dinophagous dinoflagellate genus Amoebophrya infect the same host species. Environ Microbiol 5: 1046-1052

Salomon PS, Granéli E, Neves MHCB, Rodriguez EG (2009) Infection by Amoebophrya spp. parasitoids of dinoflagellates in a tropical marine coastal area. Aquat Microb Ecol 55:143-153

Sepulveda J, Pantoja S, Hughen K, Lange C and others (2005) Fluctuations in export productivity over the last century from sediments of a southern Chilean fjord $\left(44^{\circ} \mathrm{S}\right)$. Estuar Coast Shelf Sci 65:587-600
Siano R, Alves-de-Souza C, Foulon E, Bendif EIM, Simon N, Guillou L, Not F (2011) Distribution and host diversity of Amoebophryidae parasites across oligotrophic waters of the Mediterranean Sea. Biogeosciences 8:267-278

Smayda TJ (1997) Harmful algal blooms: their ecophysiology and general relevance to phytoplankton blooms in the sea. Limnol Oceanogr 42:1137-1153

Strickland JDH, Parsons TR (1972) A practical handbook of seawater analysis. Fisheries Research Board of Canada, Ottawa

Tamura K, Peterson D, Peterson N, Stecher G, Nei M, Kumar S (2011) MEGA5: molecular evolutionary genetics analysis using maximum likelihood, evolutionary distance, and maximum parsimony methods. Mol Biol Evol 28: 2731-2739

Taylor FJR (1968) Parasitism of the toxin-producing dinoflagellate Gonyaulax catenella by the endoparasitic dinoflagellate Amoebophrya ceratii. J Fish Res Board Can 25:2241-2245

ter Braak CJ (1995) Ordination. In: Jongman RH, ter Braak CJ, Van Tongeren OF (eds) Data analysis and community and landscape ecology. Cambridge University Press, Cambridge, p 91-73

Torres R, Frangópulos M, Hamamé M, Montecino V and others (2011) Nitrate to silicate ratio variability and the composition of micro-phytoplankton blooms in the innerfjord of Seno Ballena (Strait of Magellan, 54 ${ }^{\circ} \mathrm{S}$ ). Cont Shelf Res 31:244-253

Uhelinger V (1964) Étude statistique des methods de dénobrement planctonique. Arch Sci 17:121-223

Uribe JC, Ruiz M (2001) Gymnodinium brown tide in the Magellanic fjords, southern Chile. Rev Biol Mar Oceanogr 36:155-164

Utermöhl H (1958) Zur Vervollkommnung der quantitativen Phytoplankton-Methodik. Mitt Int Ver Theor Angew Limnol 9:1-38

Van Valen L (1973) A new evolutionary law. Evol Theory 1: 1-30

Yih W, Coats DW (2000) Infection of Gymnodinium sanguineum by the dinoflagellate Amoebophrya sp.: effect of nutrient environment on parasite generation time, reproduction, and infectivity. J Eukaryot Microbiol 47: 504-510 
Appendix 1. Complete list of obtained sequences. $\mathrm{ES}=$ environmental samples, $\mathrm{SC}=$ single cells

\begin{tabular}{|c|c|c|c|c|c|c|}
\hline $\begin{array}{l}\text { GenBank } \\
\text { number }\end{array}$ & ID & Organism & Host & Source & Geographical area & $\begin{array}{l}\text { MALV II } \\
\text { clade }\end{array}$ \\
\hline JN998202 & RL_Dacum_cell1_clone01 & 1 Amoebophrya sp. I & Dinophysis acuminata & $\mathrm{SC}$ & Reloncaví Fjord, Chile & 4 \\
\hline JN998203 & RL_Dacum_cell1_clone02 & 2 Amoebophrya sp. & D. acuminata & $\mathrm{SC}$ & Reloncaví Fjord, Chile & 4 \\
\hline JN998204 & RL_Dacum_cell1_clone 0 & 3 Amoebophrya sp. & D. acuminata & $\mathrm{SC}$ & Reloncaví Fjord, Chile & 4 \\
\hline JN998205 & RL_Dacum_cell2_clone 0 & 1 Amoebophrya sp. & D. acuminata & $\mathrm{SC}$ & Reloncaví Fjord, Chile & 4 \\
\hline JN998206 & RL_Dacum_cell2_clone 0 & 2 Amoebophrya sp. & D. acuminata & $\mathrm{SC}$ & Reloncaví Fjord, Chile & 4 \\
\hline JN998207 & RL_Dacum_cell2_clone 03 & 3 Amoebophrya sp. & D. acuminata & $\mathrm{SC}$ & Reloncaví Fjord, Chile & 4 \\
\hline JN998208 & RL_Prot_cell1_clone 01 & Amoebophrya sp. $P$ & Phalachroma rotundata & $\mathrm{SC}$ & Reloncaví Fjord, Chile & 4 \\
\hline JN998209 & RL_Prot_cell1_clone 02 & Amoebophrya sp. & P. rotundata & $\mathrm{SC}$ & Reloncaví Fjord, Chile & 4 \\
\hline JN998210 & RL_Prot_cell2_clone 01 & Amoebophrya sp. & P. rotundata & $\mathrm{SC}$ & Reloncaví Fjord, Chile & 4 \\
\hline JN998211 & RL_Prot_cell2_clone 02 & Amoebophrya sp. & P. rotundata & $\mathrm{SC}$ & Reloncaví Fjord, Chile & 4 \\
\hline JN998212 & RL_Prot_cell2_clone 03 & Amoebophrya sp. & P. rotundata & $\mathrm{SC}$ & Reloncaví Fjord, Chile & 4 \\
\hline JN998213 & RL_Pmic_01 & Amoebophrya sp. & Prorocentrum micans & $\mathrm{SC}$ & Reloncaví Fjord, Chile & 4 \\
\hline JQ038241 & CN_Pmic_01 & Amoebophrya sp. & P. micans & $\mathrm{SC}$ & Concarneau Bay, France & 4 \\
\hline JN998214 & CN_Pmic_02 & Amoebophrya sp. & P. micans & $\mathrm{SC} \quad$ & Concarneau Bay, France & 4 \\
\hline JN998215 & RL_10Jan_01 & Uncultured Syndiniales & Unknown & ES & Reloncaví Fjord, Chile & 4 \\
\hline JN998216 & RL_10Jan_02 & Uncultured Syndiniales & Unknown & ES & Reloncaví Fjord, Chile & 4 \\
\hline JN998217 & RL_10Jan_03 & Uncultured Syndiniales & Unknown & ES & Reloncaví Fjord, Chile & 4 \\
\hline JN998218 & RL_10Jan_04 & Uncultured Syndiniales & Unknown & ES & Reloncaví Fjord, Chile & 4 \\
\hline JN998219 & RL_10Jan_05 & Uncultured Syndiniales & Unknown & ES & Reloncaví Fjord, Chile & 4 \\
\hline JN998220 & RL_10Jan_06 & Uncultured Syndiniales & Unknown & ES & Reloncaví Fjord, Chile & 4 \\
\hline JN998221 & RL_10Jan_07 & Uncultured Syndiniales & Unknown & ES & Reloncaví Fjord, Chile & 4 \\
\hline JN998222 & RL_10Jan_08 & Uncultured Syndiniales & Unknown & ES & Reloncaví Fjord, Chile & 4 \\
\hline JN998223 & RL_10Jan_09 & Uncultured Syndiniales & Unknown & ES & Reloncaví Fjord, Chile & 4 \\
\hline JN998224 & RL_10Jan_10 & Uncultured Syndiniales & Unknown & ES & Reloncaví Fjord, Chile & 4 \\
\hline JN998225 & RL_14Feb_01 & Uncultured Syndiniales & Unknown & ES & Reloncaví Fjord, Chile & 4 \\
\hline JN998226 & RL_14Feb_02 & Uncultured Syndiniales & Unknown & ES & Reloncaví Fjord, Chile & 4 \\
\hline JN998227 & RL_14Feb_03 & Uncultured Syndiniales & Unknown & ES & Reloncaví Fjord, Chile & 4 \\
\hline JN998228 & RL_14Feb_04 & Uncultured Syndiniales & Unknown & ES & Reloncaví Fjord, Chile & 4 \\
\hline JN998229 & RL_14Feb_05 & Uncultured Syndiniales & Unknown & ES & Reloncaví Fjord, Chile & 4 \\
\hline JN998230 & RL_14Feb_06 & Uncultured Syndiniales & Unknown & ES & Reloncaví Fjord, Chile & 4 \\
\hline JN998231 & RL_14Feb_07 & Uncultured Syndiniales & Unknown & ES & Reloncaví Fjord, Chile & 4 \\
\hline JN998232 & RL_14Feb_08 & Uncultured Syndiniales & Unknown & ES & Reloncaví Fjord, Chile & 4 \\
\hline JN998233 & RL_14Feb_09 & Uncultured Syndiniales & Unknown & ES & Reloncaví Fjord, Chile & 4 \\
\hline JN998234 & RL_14Feb_10 & Uncultured Syndiniales & Unknown & ES & Reloncaví Fjord, Chile & 4 \\
\hline JN998235 & RL_14Feb_11 & Uncultured Syndiniales & Unknown & ES & Reloncaví Fjord, Chile & 4 \\
\hline JN998236 & RL_14Feb_12 & Uncultured Syndiniales & Unknown & ES & Reloncaví Fjord, Chile & 4 \\
\hline JN998237 & RL_14Feb_13 & Uncultured Syndiniales & Unknown & ES & Reloncaví Fjord, Chile & 4 \\
\hline JN998238 & RL_14Feb_14 & Uncultured Syndiniales & Unknown & ES & Reloncaví Fjord, Chile & 4 \\
\hline JN998239 & RL_14Feb_15 & Uncultured Syndiniales & Unknown & ES & Reloncaví Fjord, Chile & 4 \\
\hline JN998240 & RL_14Feb_16 & Uncultured Syndiniales & Unknown & ES & Reloncaví Fjord, Chile & 4 \\
\hline JN998241 & RL_14Feb_17 & Uncultured Syndiniales & Unknown & ES & Reloncaví Fjord, Chile & 4 \\
\hline JN998242 & RL_14Feb_18 & Uncultured Syndiniales & Unknown & ES & Reloncaví Fjord, Chile & 4 \\
\hline JN998243 & RL_14Feb_19 & Uncultured Syndiniales & Unknown & ES & Reloncaví Fjord, Chile & 4 \\
\hline JN998244 & RL_14Feb_20 & Uncultured Syndiniales & Unknown & ES & Reloncaví Fjord, Chile & 4 \\
\hline JN998245 & RL_14Feb_21 & Uncultured Syndiniales & Unknown & ES & Reloncaví Fjord, Chile & 4 \\
\hline JN998246 & RL_14Feb_22 & Uncultured Syndiniales & Unknown & ES & Reloncaví Fjord, Chile & 4 \\
\hline JN998247 & RL_14Feb_23 & Uncultured Syndiniales & Unknown & ES & Reloncaví Fjord, Chile & 4 \\
\hline JN998248 & RL_14Feb_24 & Uncultured Syndiniales & Unknown & ES & Reloncaví Fjord, Chile & 4 \\
\hline JN998249 & RL_14Feb_25 & Uncultured Syndiniales & Unknown & ES & Reloncaví Fjord, Chile & 4 \\
\hline JN998250 & RL_14Feb_26 & Uncultured Syndiniales & Unknown & ES & Reloncaví Fjord, Chile & 4 \\
\hline JN998251 & RL_14Feb_27 & Uncultured Syndiniales & Unknown & ES & Reloncaví Fjord, Chile & 4 \\
\hline JN998252 & RL_14Feb_28 & Uncultured Syndiniales & Unknown & ES & Reloncaví Fjord, Chile & 4 \\
\hline JN998253 & RL_14Feb_29 & Uncultured Syndiniales & Unknown & ES & Reloncaví Fjord, Chile & 4 \\
\hline JN998254 & RL_14Feb_30 & Uncultured Syndiniales & Unknown & ES & Reloncaví Fjord, Chile & 4 \\
\hline JN998255 & RL_14Feb_31 & Uncultured Syndiniales & Unknown & ES & Reloncaví Fjord, Chile & 4 \\
\hline JN998256 & RL_14Feb_32 & Uncultured Syndiniales & Unknown & ES & Reloncaví Fjord, Chile & 4 \\
\hline JN998257 & RL_11Mar_01 & Uncultured Syndiniales & Unknown & ES & Reloncaví Fjord, Chile & 5 \\
\hline JN998258 & RL_11Mar_02 & Uncultured Syndiniales & Unknown & ES & Reloncaví Fjord, Chile & 6 \\
\hline
\end{tabular}


Appendix 1 (continued)

\begin{tabular}{|c|c|c|c|c|c|c|}
\hline $\begin{array}{l}\text { GenBank } \\
\text { number }\end{array}$ & ID & Organism & Host & Source & Geographical area & $\begin{array}{l}\text { MALV II } \\
\text { clade }\end{array}$ \\
\hline JN998259 & RL_11Mar_03 & Uncultured Syndiniales & Unknown & ES & Reloncaví Fjord, Chile & 1 \\
\hline JN998260 & RL_11Mar_04 & Uncultured Syndiniales & Unknown & ES & Reloncaví Fjord, Chile & 6 \\
\hline JN998261 & RL_11Mar_05 & Uncultured Syndiniales & Unknown & $\mathrm{ES}$ & Reloncaví Fjord, Chile & 6 \\
\hline JN998262 & RL_11Mar_06 & Uncultured Syndiniales & Unknown & ES & Reloncaví Fjord, Chile & 6 \\
\hline JN998263 & RL_14Mar_01 & Uncultured Syndiniales & Unknown & $\mathrm{ES}$ & Reloncaví Fjord, Chile & 4 \\
\hline JN998264 & RL_14Mar_02 & Uncultured Syndiniales & Unknown & ES & Reloncaví Fjord, Chile & 4 \\
\hline JN998265 & RL_14Mar_03 & Uncultured Syndiniales & Unknown & ES & Reloncaví Fjord, Chile & 4 \\
\hline JN998266 & RL_14Mar_04 & Uncultured Syndiniales & Unknown & $\mathrm{ES}$ & Reloncaví Fjord, Chile & 4 \\
\hline JN998267 & RL_14Mar_05 & Uncultured Syndiniales & Unknown & ES & Reloncaví Fjord, Chile & 4 \\
\hline JN998268 & RL_14Mar_06 & Uncultured Syndiniales & Unknown & $\mathrm{ES}$ & Reloncaví Fjord, Chile & 4 \\
\hline JN998269 & RL_14Mar_07 & Uncultured Syndiniales & Unknown & ES & Reloncaví Fjord, Chile & 4 \\
\hline JN998270 & RL_14Mar_08 & Uncultured Syndiniales & Unknown & ES & Reloncaví Fjord, Chile & 4 \\
\hline JN998271 & RL_14Mar_09 & Uncultured Syndiniales & Unknown & $\mathrm{ES}$ & Reloncaví Fjord, Chile & 4 \\
\hline JN998272 & RL_14Mar_10 & Uncultured Syndiniales & Unknown & ES & Reloncaví Fjord, Chile & 6 \\
\hline JN998273 & RL_14Mar_11 & Uncultured Syndiniales & Unknown & $\mathrm{ES}$ & Reloncaví Fjord, Chile & 4 \\
\hline JN998274 & RL_14Mar_12 & Uncultured Syndiniales & Unknown & $\mathrm{ES}$ & Reloncaví Fjord, Chile & 4 \\
\hline JN998275 & RL_14Mar_13 & Uncultured Syndiniales & Unknown & $\mathrm{ES}$ & Reloncaví Fjord, Chile & 4 \\
\hline JN998276 & RL_14Mar_14 & Uncultured Syndiniales & Unknown & ES & Reloncaví Fjord, Chile & 4 \\
\hline JN998277 & RL_14Mar_15 & Uncultured Syndiniales & Unknown & ES & Reloncaví Fjord, Chile & 4 \\
\hline JN998278 & RL_14Mar_16 & Uncultured Syndiniales & Unknown & $\mathrm{ES}$ & Reloncaví Fjord, Chile & 4 \\
\hline JN998279 & RL_14Mar_17 & Uncultured Syndiniales & Unknown & ES & Reloncaví Fjord, Chile & 4 \\
\hline JN998280 & RL_14Mar_18 & Uncultured Syndiniales & Unknown & $\mathrm{ES}$ & Reloncaví Fjord, Chile & 4 \\
\hline JN998281 & RL_14Mar_19 & Uncultured Syndiniales & Unknown & $\mathrm{ES}$ & Reloncaví Fjord, Chile & 4 \\
\hline JN998282 & RL_14Mar_20 & Uncultured Syndiniales & Unknown & $\mathrm{ES}$ & Reloncaví Fjord, Chile & 4 \\
\hline JN998283 & RL_14Mar_21 & Uncultured Syndiniales & Unknown & $\mathrm{ES}$ & Reloncaví Fjord, Chile & 4 \\
\hline JN998284 & RL_14Mar_22 & Uncultured Syndiniales & Unknown & ES & Reloncaví Fjord, Chile & 4 \\
\hline JN998285 & RL_14Mar_23 & Uncultured Syndiniales & Unknown & $\mathrm{ES}$ & Reloncaví Fjord, Chile & 4 \\
\hline JN998286 & RL_08Mar_01 & Uncultured Syndiniales & Unknown & ES & Reloncaví Fjord, Chile & 4 \\
\hline JN998287 & RL_08Mar_02 & Uncultured Syndiniales & Unknown & ES & Reloncaví Fjord, Chile & 4 \\
\hline JN998288 & RL_08Mar_03 & Uncultured Syndiniales & Unknown & ES & Reloncaví Fjord, Chile & 12 \\
\hline JN998289 & RL_08Mar_04 & Uncultured Syndiniales & Unknown & ES & Reloncaví Fjord, Chile & 6 \\
\hline JN998290 & RL_08Mar_05 & Uncultured Syndiniales & Unknown & $\mathrm{ES}$ & Reloncaví Fjord, Chile & 12 \\
\hline JN998291 & RL_08Mar_06 & Uncultured Syndiniales & Unknown & ES & Reloncaví Fjord, Chile & 12 \\
\hline JN998292 & RL_08Mar_07 & Uncultured Syndiniales & Unknown & $\mathrm{ES}$ & Reloncaví Fjord, Chile & 12 \\
\hline JN998293 & RL_08Mar_08 & Uncultured Syndiniales & Unknown & $\mathrm{ES}$ & Reloncaví Fjord, Chile & 6 \\
\hline JN998294 & RL_08Mar_09 & Uncultured Syndiniales & Unknown & $\mathrm{ES}$ & Reloncaví Fjord, Chile & 6 \\
\hline JN998295 & RL_08Mar_10 & Uncultured Syndiniales & Unknown & ES & Reloncaví Fjord, Chile & 6 \\
\hline JN998296 & RL_08Mar_11 & Uncultured Syndiniales & Unknown & ES & Reloncaví Fjord, Chile & 4 \\
\hline JN998297 & RL_08Mar_12 & Uncultured Syndiniales & Unknown & $\mathrm{ES}$ & Reloncaví Fjord, Chile & 4 \\
\hline JN998298 & RL_08Mar_13 & Uncultured Syndiniales & Unknown & ES & Reloncaví Fjord, Chile & 4 \\
\hline JN998299 & RL_08Mar_14 & Uncultured Syndiniales & Unknown & $\mathrm{ES}$ & Reloncaví Fjord, Chile & 4 \\
\hline JN998300 & RL_08Mar_15 & Uncultured Syndiniales & Unknown & $\mathrm{ES}$ & Reloncaví Fjord, Chile & 4 \\
\hline JN998301 & RL_08Mar_16 & Uncultured Syndiniales & Unknown & ES & Reloncaví Fjord, Chile & 4 \\
\hline JN998302 & RL_08Mar_17 & Uncultured Syndiniales & Unknown & $\mathrm{ES}$ & Reloncaví Fjord, Chile & 4 \\
\hline JN998303 & RL_08Mar_18 & Uncultured Syndiniales & Unknown & ES & Reloncaví Fjord, Chile & 4 \\
\hline JN998304 & RL_08Mar_19 & Uncultured Syndiniales & Unknown & ES & Reloncaví Fjord, Chile & 4 \\
\hline JN998305 & RL_08Mar_20 & Uncultured Syndiniales & Unknown & ES & Reloncaví Fjord, Chile & 4 \\
\hline JN998306 & RL_08Mar_21 & Uncultured Syndiniales & Unknown & ES & Reloncaví Fjord, Chile & 4 \\
\hline JN998307 & RL_08Mar_22 & Uncultured Syndiniales & Unknown & ES & Reloncaví Fjord, Chile & 4 \\
\hline JN998308 & RL_08Mar_23 & Uncultured Syndiniales & Unknown & ES & Reloncaví Fjord, Chile & 4 \\
\hline JN998309 & RL_08Mar_24 & Uncultured Syndiniales & Unknown & $\mathrm{ES}$ & Reloncaví Fjord, Chile & 4 \\
\hline JN998310 & RL_08Mar_25 & Uncultured Syndiniales & Unknown & ES & Reloncaví Fjord, Chile & 4 \\
\hline JN998311 & RL_08Mar_26 & Uncultured Syndiniales & Unknown & $\mathrm{ES}$ & Reloncaví Fjord, Chile & 4 \\
\hline JN998312 & RL_08Mar_27 & Uncultured Syndiniales & Unknown & ES & Reloncaví Fjord, Chile & 4 \\
\hline
\end{tabular}

